\title{
Purification and Properties of Herpesvirus saimiri DNA ${ }^{1}$
}

\author{
BERNHARD FLECKENSTEIN AND HANS WOLF
}

\author{
Institut für Klinische Virologie der Universität ${ }^{2}$ Erlangen-Nürnberg, 852 Erlangen, Germany
}

Accepted November 6, 1973

\begin{abstract}
${ }^{3} \mathrm{H}$-Thymidine-labeled Herpesvirus saimiri (HVS) was purified from supernatant and cells of infected owl monkey kidney monolayer cultures. Pronase/SDS-extracted HVS DNA was characterized in neutral sucrose gradients. Cocentrifugation of this DNA with ${ }^{14} \mathrm{C}$-labeled T4-phage DNA resulted in $s_{20, \mathrm{w}}^{0}=58 \pm 1.5 \mathrm{~S}$ as the sedimentation constant, corresponding to a molecular weight of $91 \pm 5 \times 10^{6}$ daltons. Unsheared HVS DNA banded in cesium chloride at $1.709 \mathrm{~g} / \mathrm{ml}$, but it broke down during the different manipulations to at least two double-stranded DNA molecules of largely different base composition which shared no sequence homologies. One part ( $42 \%$ of the total viral genome) had a density of $1.729 \mathrm{~g} / \mathrm{ml}$, corresponding to $70 \%$ cytosine plus guanine content, the other one (representing $58 \%$ of the intact molecule) banded at $1.694 \mathrm{~g} / \mathrm{ml}$, corresponding to $35 \%$ cytosine plus guanine.
\end{abstract}

\section{INTRODUCTION}

Three members of the herpesvirus group, Herpesvirus saimiri (HVS), Herpesvirus ateles (HVA), and Epstein Barr virus (EBV) cause tumors in subhuman primates. EBV is suspected to be involved in the etiology of Burkitt's lymphoma (Epstein et al., 1964) and nasopharyngeal carcinoma by virtue of immunological studies (Henle et al., 1969; Klein et al., 1970) and the demonstration of EBV DNA homologies in tumor biopsies (zur Hausen et al., 1970) and tumor cells (Wolf et al., 1973). Its in vivo oncogenicity was recently demonstrated by Shope ot al. (1973) and Epstein et al. (1973), who induced lymphoproliferative disease in marmoset (Saguinus oedipus) or owl monkeys (Aotus trivirgatus) by inoculation of $\mathrm{EBV}$ derived from lymphoblastoid cell lines.

HVS was first isolated from squirrel monkey (Saimiri sciureus) kidney cell cultures by Melendez et al. (1968). Marmosets (Saguinus oedipus, S. nigricollis, S. fuscicollis) inoculated with HVS consistently developed malignant lymphomas or acute

${ }^{1}$ Supported by the Deutsche Forschungsgemeinschaft, Bad Godesberg and SFB 118.

${ }^{2}$ Part of the work was done in the HygieneInstitut der Universität Göttingen, Germany. lymphocytic leukemias within a few weeks after inoculation (Melendez et al., 1969; Wolfe et al., 1971; Laufs and Fleckenstein, 1972, 1973). HVS also induced malignant lymphoproliferative diseases in various other species of new world monkeys although these are less susceptible to HVS than marmosets (reviewed by Deinhardt et al., 1973).

Infections by HVS parallel EBV infections of man in many regards: (1) The natural host harbors the virus in peripheral leukocytes persistently (Falk et al., 1972a) and reveals antibodies to virus-specific late antigens (Klein et al., 1973). Antibodies against early antigens are only produced in recently infected or tumor-bearing individuals. (2) Herpesvirus particles have not been seen in fresh biopsy cells by electron microscopy (Ablashi et al., 1971) nor were viral structural components revealed by immunofluorescent methods (Falk et al., 1972b). (3) Lymphoblastoid cell lines of similar morphology have been established from EBV - and HVSinduced lymphomas (Rabson et al., 1971; Falk et al., 1972b). A small proportion of these tissue culture cells produces viral antigens and infectious viral particles.

In contrast to EBV, HVS can be propagated in certain tissue culture cells. The 
HVS system provides therefore a useful model for studying oncogenic herpesvirushost cell interactions. To investigate the role of HVS in transformation of lymphatic cells by molecular hybridization experiments, we purified the viral DNA. The present study describes purification procedures of HVS-DNA. In addition, its sedimentation constant, molecular weight, and base composition is reported.

\section{MATERIALS AND METHODS}

Viruses and cell culture. Strains S $295 \mathrm{C}$ and E $940 \mathrm{~F}$ of HVS were kindly supplied by Dr. Melendez, strain E 515 I was furnished by Dr. Daniel, and Strain No. 11 was provided by Dr. Falk. The virus was usually propagated in Vero cells and in two owl monkey kidney (OMK) cell lines which have been established by Dr. Daniel. The mostly used strain S $295 \mathrm{C}$ was plaquepurified under methyl cellulose in the presence of tylosine, gentamycin, and kanamycin. The virus-infected cells were kept at $35^{\circ}$ without addition of antibiotics. Herpes simplex virus type 2 was plaque-purified and propagated in Vero cells.

The cells were cultivated in minimal essential medium (MEM) supplemented with $2 \%$ heat-inactivated fetal calf serum and $8 \%$ calf serum.

Tests for mycoplasma contamination. Attempts to isolate mycoplasms from tissue cultures were carried out by Dr. W. Bredt at the Institut für Medizinische Mikrobiologie, Mainz, as well as in our laboratory. Tissue culture cells and $0.5 \mathrm{ml}$ of supernatant were incubated under $10 \% \mathrm{CO}_{2}$ for 2 weeks in PPLO-Broth (Difco) supplemented with $20 \% \quad(\mathrm{v} / \mathrm{v})$ PPLO-serum fraction (Difco), $1 \%$ yeast extract (Difco), minimum essential vitamins (Flow), $10 \mathrm{~m} M$ arginine, $10 \mathrm{~m} M$ glutamine, $0.5 \%$ glucose, and 300 $\mathrm{U}$ of penicillin per milliliter.

In addition, the cultures were screened for the presence of mycoplasmal uridine phosphorylase according to Levine (1972). Six $\times 10^{6}$ cells were incubated in $0.05 M$ sodium phosphate buffer $(\mathrm{pH} 8.1)$ with 1 mmole uracil and $0.5 \%$ Triton $\mathrm{X}$-100 for 20 min at $20^{\circ}$. The suspension was then clarified by low speed centrifugation, and $20 \mu \mathrm{Ci} / \mathrm{ml}$ ${ }^{3} \mathrm{H}$-uridine (Amersham-Buchler, Braun- schweig), specific activity $0.5 \mathrm{Ci} / \mathrm{mmole}$, were added. The reaction was carried out at $37^{\circ}$ over $3 \mathrm{hr}$. Uridine and uracil were separated by ascending paper chromatography. Conversion rates to uracil of more than $15 \%$ were regarded as indicative for mycoplasma contamination.

Infection and radioactive labeling. HVSinfected OMK cells were refed 2 days after infection with $\mathrm{MEM} / 10 \%$ heat-inactivated calf serum containing 0.5 to $1.5 \mu \mathrm{Ci} / \mathrm{ml}$ ${ }^{3} \mathrm{H}$-thymidine (specific activity 15-27 Ci/ mmole). The virus was harvested 4-8 days p.i., when marked cytopathic changes occurred. At this time, the infectivity titers ranged up to $10^{6} \mathrm{PFU} / \mathrm{ml}$. Vero cells yielded about $10^{4} \mathrm{PFU} / \mathrm{ml}$ if trypsinized 3 days after infection with HVS and harvested 2-4 days later.

Partial purification of viruses. HVS was purified by four methods.

1. The supernatant of infected tissue cultures was clarified by low speed centrifugation. From this, the virus was concentrated by two subsequent pellet centrifugations in the Spinco type 19 rotor at $19,000 \mathrm{rpm}$ for $2 \mathrm{hr}$ and the Spinco SW 27 rotor at 17,000 rpm for $90 \mathrm{~min}$. The virus was resuspended in reticulocyte standard buffer (RSB; Warner et al., 1963), layered on a $15-30 \%(w / w)$ sucrose gradient, and centrifuged in the SW 27 rotor at $20,000 \mathrm{rpm}$ for $35 \mathrm{~min}$ at $4^{\circ}$. Fractions of 20 drops were collected from the bottom of the tubes. Radioactivity was determined in a toluene scintillator with $33 \%(\mathrm{v} / \mathrm{v})$ Triton X-100. In some experiments infectious virus of each fraction was titrated in OMK cells. Part of the fractions was vacuum-dialyzed against $\mathrm{RSB}$, negatively stained with saturated uranyl acetate or $2 \%(\mathrm{w} / \mathrm{v})$ phosphotungstic acid at $\mathrm{pH}$ 7.2 , and examined in a Zeiss EM 10 electron microscope.

2. Concentrated virus pellets from tissue culture supernatants were resuspended in $1 \%$ Nonidet P-40 (NP-40; nonionic detergent, Shell Oil Co.) solution in $10^{-2} M$ Tris buffer $(\mathrm{pH} 7.4)$ and incubated for $60 \mathrm{~min}$ at $37^{\circ}$. The suspension was clarified by centrifugations at 2000 and $12,000 \mathrm{~g}$. Nucleocapsids released by NP-40 were centrifuged as reported above.

3. Cell-bound HVS was recovered by a 
method analogous to that described by Weinberg and Becker (1969). Cytoplasm of infected cells was lysed by addition of $0.5 \%$ NP-40 in $10^{-2} M$ Tris buffer containing $8 \%$ $(w / w)$ sucrose. Nuclei were discarded after low speed centrifugation. Sedimentation conditions for the freed nucleocapsids were reported above.

4. The infected cells were suspended in RSB for $3 \mathrm{hr}$ at $4^{\circ}$, dounced, and briefly sonicated. Nuclei and cytoplasmic debris were removed by low speed centrifugation before layering the supernatant on 15 to $30 \%(\mathrm{w} / \mathrm{w})$ sucrose gradients.

Purification of viral DNA. The viruscontaining fractions were pooled, diluted with RSB, and centrifuged in the SW 27 rotor at $17,000 \mathrm{rpm}$ for $90 \mathrm{~min}$. The pellet was incubated for 30 min at $37^{\circ}$ in RSB containing $1 \mathrm{mg}$ of Pronase per milliliter, $1 \%$ sodium dodecyl sulfate (SDS), $0.01 \mathrm{M}$ EDTA on the top of a 20 to $35 \%(\mathrm{w} / \mathrm{w})$ sucrose-SDS gradient (zur Hausen and Schulte-Holthausen, 1970). Released DNA was spun in the SW 27 rotor at $20,000 \mathrm{rpm}$ at $25^{\circ}$ for $14 \mathrm{hr}$. Peak fractions were diluted with $0.1 \times \mathrm{SSC}(\mathrm{SSC}=0.15 \mathrm{M} \mathrm{NaCl}$ plus $0.015 M$ citrate) and centrifuged in the SW 41 rotor at $38,000 \mathrm{rpm}$ for $16 \mathrm{hr}$ at $25^{\circ}$. The pelleted DNA was resuspended in 0.1 $X$ SSC. Solid cesium chloride was added to obtain a density of $1.7 \mathrm{~g} / \mathrm{ml}$. The samples were centrifuged at $39,000 \mathrm{rpm}$ for $60 \mathrm{hr}$ at $25^{\circ}$ in the Spinco $\mathrm{Ti} 50$ rotor or in the Christ-Type 60 fixed-angle rotor.

Preparation of T4-Phage DNA. T4 $\mathrm{B}+$ phage growing on Escherichia coli B $/ 5$ was labeled with $0.1 \quad \mu \mathrm{Ci} / \mathrm{ml} \quad{ }^{14} \mathrm{C}$-thymidine (Amersham-Buchler, Braunschweig, specific activity $62 \mathrm{mCi} / \mathrm{mmole}$ ). The phage was concentrated by sedimentation in the $\mathrm{SW}$ 27 rotor at $17,000 \mathrm{rpm}$ for $30 \mathrm{~min}$ and purified in a preformed 32 to $56 \%(\mathrm{w} / \mathrm{w})$ cesium chloride gradient in the SW 50 rotor at $39,000 \mathrm{rpm}$ for $90 \mathrm{~min}$. The particles were disrupted by adding a solution of $1 \%$ SDS, $2 \%$ sarkosyl NL (Ciba-Geigy), $1 \mathrm{mg}$ of Pronase per milliliter, and $0.01 M$ EDTA and by incubation for $30 \mathrm{~min}$ at $37^{\circ}$ and thereafuer for $10 \mathrm{~min}$ at $60^{\circ}$.

$D N A-D N A$ filter hybridization. To obtain cold cellular DNA, tissue culture cells were lysed with $2 \%$ sarkosyl, digested with $1 \mathrm{mg}$ of Pronase per milliliter for $30 \mathrm{~min}$ at $37^{\circ}$, and subsequently extracted with phenol and chloroform $-4 \%(\mathrm{v} / \mathrm{v})$ isoamyl alcohol. The nucleic acids were incubated with $50 \mu \mathrm{g}$ of RNase per milliliter for $30 \mathrm{~min}$ at $37^{\circ}$, reextracted with phenol and chloroformisoamyl alcohol, precipitated with ethanol, dissolved in $0.1 \times \mathrm{SSC}$, and dialyzed against $0.1 \times$ SSC. Absorption between 220 and $320 \mathrm{~nm}$ was scanned in a Gilford Type 240 spectrophotometer.

Purified DNA was heat-denatured by boiling for 15 min followed by rapid cooling in ice water. The heat-denatured DNA was brought up to $2 \times \mathrm{SSC}$ and slowly filtered through $0.45 \mu \mathrm{m}$ nitrocellulose filters (Sartorius, Göttingen, SM 11,306). The filters were incubated for $4 \mathrm{hr}$ at $80^{\circ}$.

Purified radioactive viral DNA was dialyzed against $0.1 \times$ SSC to remove $\mathrm{CsCl}$. The DNA was disintegrated by sonification, heat denatured, and incubated with filters in $1.5 \mathrm{ml} 4 \times \mathrm{SSC}, 0.1 \%$ SDS for $16 \mathrm{hr}$ at $66^{\circ}$. The filters were washed with $100 \mathrm{ml}$ of $2 \times$ SSC before monitoring radioactivity.

$D N A-c R N A$ filter hybridization. Purified HVS DNA, 1-3 $\mu \mathrm{g}$, was transcribed in vitro with $E$. coli-RNA polymerase to ${ }^{3} \mathrm{H}$-labeled cRNA (specific activity 4.1-5.3 $\times 10^{7} \mathrm{dpm} /$ $\mu \mathrm{g})$ as described by zur Hausen and SchulteHolthausen (1972). After heat denaturation, about $5 \times 10^{-4} \mu \mathrm{g} \mathrm{cRNA} / \mathrm{ml}$ (in $2.5 \times$ SSC, $50 \%$ formamide, and $0.05 \%$ SDS) were added to each DNA-loaded filter, which was gently shaken over 7 days at $45^{\circ}$. Thereafter, the filters were washed with $2 \times \mathrm{SSC}$, treated with $20 \mu \mathrm{g} / \mathrm{ml}$ RNase (Merck, Darmstadt) for $30 \mathrm{~min}$ at $37^{\circ}$, washed again, and counted.

Digestion of single-stranded DNA. Singlestrand-specific $\mathrm{S1}$ nuclease was prepared from Aspergillus oryzae amylase (Sankyo Co., Tokyo) according to the method given by Sutton (1971). Single-strand degradation was carried out in $0.03 M$ acetate buffer $\mathrm{pH}$ 4.5 containing $1.8 \times 10^{-3} \mathrm{M} \mathrm{ZnCl}_{2}, 0.3 \mathrm{M}$ $\mathrm{NaCl}, 10 \mu \mathrm{g} / \mathrm{ml}$ heat-denatured and 50 $\mu \mathrm{g} / \mathrm{ml}$ native calf thymus DNA for $1 \mathrm{hr}$ at $45^{\circ}$ (Leong et al., 1972). Trichloroacetic acid (TCA)-precipitable radioactivity was collected on $0.45 \mu \mathrm{m}$ nitrocellulose filters and counted in toluene-Triton X-100 scintillalor. 

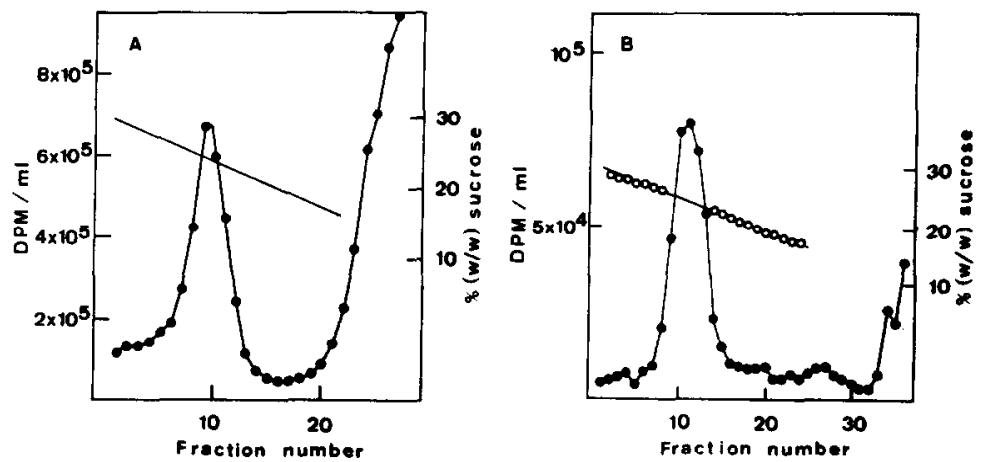

FIG. 1. Sedimentation of ${ }^{3} \mathrm{H}$-thymidine-labeled HVS in $15-30 \%(\mathrm{w} / \mathrm{w})$ sucrose gradients. (A) Complete herpesvirus particles were concentrated from OMK-cell supernatant by pellet centrifugations prior to sucrose sedimentation. In experiment (B) HVS-nucleocapsids were released from viral concentrates by $1 \%$ NP-40 before layering on sucrose. Direction of sedimentation is to the left.

\section{RESULTS}

Sedimentation of HVS in Sucrose Gradients

By sedimenting complctc HVS-particlcs recovered from OMK-cell cytoplasm (method 4) or from tissue culture supernatants (method 1) in $15-30 \%$ (w/w) sucrose gradients, a visible band was observed between the lower and middle third of the tube. This band corresponded to a peak of radioactivity (Fig. 1A). Electron microscopy revealed that it consisted of complete herpesvirus particles, of nucleocapsids partially penetrated by the stain, most of them surrounded by irregularly shaped envelopes. Slowly sedimenting DNA at the top of the gradient could be digested by DNase, whereas the virus band remained TCAprecipitable after DNase treatment.

When concentrated HVS was resuspended in $1 \% \mathrm{NP}-40$, free nucleocapsids were released, sedimenting as a sharp radioactivity peak in the 15 to $30 \%(\mathrm{w} / \mathrm{w})$ sucrose gradient (Fig. 1B).

Sedimentation of DNA in the Neutral Sucrose-SDS Gradient

HVS DNA was released from partially purified virus concentrates by Pronase and SDS on top of the gradient. After centrifugation, a sharp peak of radioactivity was found in fractions $8-10$ of about 30 fractions. Cosedimentation of ${ }^{3} \mathrm{H}-\mathrm{HVS}$ DNA with ${ }^{14} \mathrm{C}$-labeled T4-phage DNA revealed a $93 \pm$ $2 \%$ sedimentation distance of HVS DNA as compared with phage DNA (Fig. 2). Taking

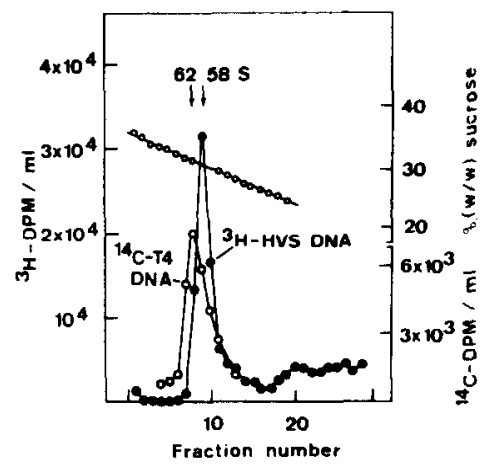

FIG. 2. Sedimentation of ${ }^{3} \mathrm{H}$-thymidine-labeled HVS DNA in a neutral sucrose-SDS gradient. Partially purified virus was lysed with Pronase and SDS on top of the gradient. Released ${ }^{3} \mathrm{H}-\mathrm{HVS}$ DNA (-) cosedimented with ${ }^{{ }^{14}} \mathrm{C}$-labeled $\mathrm{T4}$ phage DNA (O- $\mathrm{O})$. Direction of sedimentation is to the left.

$s_{20, w}^{0}=62 \pm 0.7 \mathrm{~S}$ as the sedimentation constant of T4 DNA (Gray and Hearst, 1968) and applying Burgi and Hershey's (1963) approximative relationship, the $s_{20, w}^{0}$ of HVS DNA was calculated to be $58 \pm$ $1.5 \mathrm{~S}$. For herpes simplex type $2 \mathrm{DNA}$, a value of $59 \pm 1.5 \mathrm{~S}$ resulted.

\section{Density Centrifugation of Prepurified Viral $D N A$}

The HVS DNA-containing peak fractions of the sucrose-SDS gradient were used for further density analysis. In all of 17 experiments, the HVS DNA banded over a broad density range in cesium chloride gradients (Fig. $3 \Lambda$ ). About $60 \%$ of the total radio- 

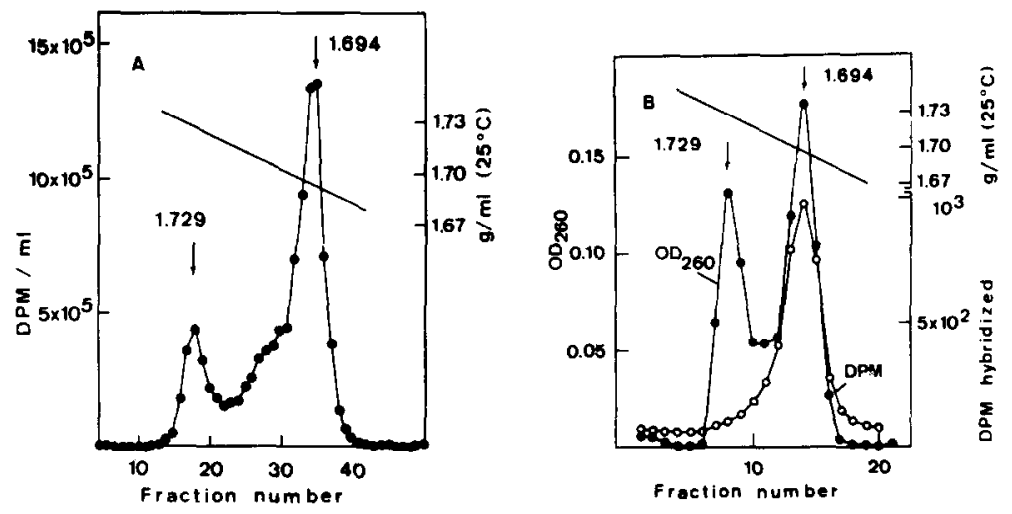

Fig. 3. Cesium chloride density centrifugation of prepurified HVS DNA. (A) After centrifugation of ${ }^{3} \mathrm{H}$-thymidine-labeled DNA for $60 \mathrm{hr}$ at $39,000 \mathrm{rpm}$ in a fixed-angle rotor, two clearly separated peaks appeared at $1.729 \mathrm{~g} / \mathrm{ml}$ ( $\mathrm{H}$ fragment) and $1.694 \mathrm{~g} / \mathrm{ml}$ (L fragment). (B) Nonlabeled HVS DNA, determined by its optical density (-O), was hybridized fractionwise with 'H-labeled L-DNA. Hybridization rates are given by cross-hybridization between $\mathrm{L}$ and $\mathrm{H}$ fragments.

activity banded at a density of $1.694 \mathrm{~g} / \mathrm{ml}$. A second smaller peak, representing about $20 \%$ of the radioactivity, was found at a considerably higher densily. The buoyant density of this heavier DNA species derived from HVS was determined to be $1.729 \pm$ $0.002 \mathrm{~g} / \mathrm{ml}$ at $25^{\circ}$ by recentrifugation with ${ }^{14} \mathrm{C}$-thymidine labeled herpes simplex type 1 DNA and DNA from Micrococcus lysodeikticus and Vero cells.

The DNA of both peaks was resistant to digestion with single strand-specific S1nuclease, but it was digested after heat denaturation prior to S1-nuclease treatment (Table 1).

Following the equation given by Schildkraut et al. (1962), the heavy (H) HVS DNA $(1.729 \mathrm{~g} / \mathrm{ml})$ has a base composition of $70 \%$ cytosine and guanine $(\mathrm{C}+\mathrm{G})$ whereas the light $(\mathrm{L})$ one $(1.694 \mathrm{~g} / \mathrm{ml})$ contains $35 \% \mathrm{C}+\mathrm{G}$. Hence it can be expected that the $\mathrm{L}$ portion of ${ }^{3} \mathrm{H}$-thymidine-labeled HVS DNA may have a 2.2-fold higher specific activity than the $\mathbf{H}$ portion. This should indicate that the $\mathrm{H}$ portion constitutes about $42 \%$ of the total HVS genome, the $\mathrm{L}$ portion about $58 \%$ of it.

In some experiments a shoulder within the radioactivity profile appeared between the two characteristic peaks at a density of about $1.709 \mathrm{~g} / \mathrm{ml}$ (Fig. 3A).
TABLE 1

Treatment of the Heavy (H) and Light (L) Fragment of HVS-DNA with Single-STtrandSPECIFIC S1 Nuclease

\begin{tabular}{lrc}
\hline & \multicolumn{2}{c}{ TCA-precipitable dpm } \\
\cline { 2 - 3 } & H fragment & L fragment \\
\hline Native DNA & 2075 & 845 \\
Heat-denatured DNA & 91 & 33 \\
Controls without S1 & 2175 & 907 \\
nuclease & & \\
\hline
\end{tabular}

\section{Hybridization Studies with Light and Heavy HVS DNA}

Radioactive HVS DNA of the $\mathrm{L}$ and $\mathrm{H}$ density peaks was tested for homology to cellular DNA by molecular hybridization. Representative ${ }^{3} \mathrm{H}$-HVS DNA fractions were incubated with $50 \mu \mathrm{g}$ DNA which was extracted from uninfected OMK cells and immobilized on membrane filters. No significant hybridization with cellular DNA was seen (Table 2). However, high hybridization ratios (up to $22 \%$ ) were obtained with DNA extracted from HVS-infected OMK and Vero cells.

DNA from nonradioactive virions was purified by sedimentation in sucrose-SDS gradients and centrifuged to equilibrium in cesium chloride. By measuring the optical density at $260 \mathrm{~nm}$, the $\mathrm{H}$ portion constituted $42 \%$ of the total HVS genome, the L portion 
TABLE 2

Hybridization of HVS-DNA Fragmexts wrth DNA from Virus-Inflictid and Uninfactied Clellos ${ }^{a}$

\begin{tabular}{|c|c|c|c|c|c|}
\hline \multirow[t]{2}{*}{ Fragment } & \multirow{2}{*}{$\begin{array}{l}\text { Fraction } \\
\text { Fig. } 3 \mathrm{~A}\end{array}$} & \multirow[t]{2}{*}{ Apm added } & \multicolumn{3}{|c|}{ DNA source } \\
\hline & & & $\begin{array}{l}\text { HVS-infected } \\
\text { OMK cells }\end{array}$ & $\begin{array}{l}\text { HVS-infected } \\
\text { Vero cells }\end{array}$ & $\begin{array}{l}\text { Uninfected } \\
\text { OMK-cells }\end{array}$ \\
\hline Heavy (H) HVS-DNA & 18 & 12,800 & $23.6 \%$ & $8.1 \%$ & $0.5 \pm 0.3 \%$ \\
\hline Intermediate & 28 & 22,500 & $21.4 \%$ & - & 0.7 \\
\hline \multirow[t]{4}{*}{ Light (L) HVS-DNA } & 31 & 13,220 & $22.3 \%$ & $12.9 \%$ & $1.5 \pm 0.5 \%$ \\
\hline & 33 & 15,600 & $18.9 \%$ & $10.7 \%$ & $0.5 \pm 0.05 \%$ \\
\hline & 34 & 38,000 & $23.2 \%$ & $7.5 \%$ & $0.8 \pm 0.3 \%$ \\
\hline & 36 & 61,000 & $12.8 \%$ & - & $0.4 \%$ \\
\hline
\end{tabular}

${ }^{a}$ Herpesvirus saimiri DNA was purified by sedimentation in neutral sucrose-SDS gradients and banded over a broad density range in $\mathrm{CsCl}$ (Fig. 3A). Representative DNA samples of each density were annealed with $50 \mu \mathrm{g}$ of cold DNA extracted from HVS-infected Vero and OMK cells, but not from uninfected cells. Hybridization efficiency $(\%)=\mathrm{dpm}$ bound to filters/dpm added to reaction mixture $\times 100$.

$58 \%$ (Fig. 3B). The DNA of each fraction was dialyzed against $0.1 \times \mathrm{SSC}$, immobilized on filters, and hybridized with ${ }^{3} \mathrm{H}-$ thymidine labeled L-DNA. The $\mathrm{H}$ and $\mathrm{L}$ portions of the HVS genome did not crosshybridize (Fig. 3B).

Hybridization Studies with $c R N A$ Transcribed from Light and Heavy HVS DNA

To analyze in more detail the specificity of the annealing reactions with HVS DNA, cRNA-DNA hybridizations were carried out. The low yield of HVS DNA did not permit a continuation of DNA-DNA hybridizations on a larger scale. The cRNA derived from both HVS-DNA portions hybridized to about $20-50 \%$ of the input with $50 \mu \mathrm{g}$ of DNA derived from HVSinfected OMK cells. This was independent of virus strains and cell lines used (Table 3 ). The hybridization efficiencies with DNA from uninfected monolayer cells were $0.4-$ $1.7 \%$ (Table 3 ).

L-DNA specific eRNA was also annealed with fragments of purified nonradioactive HVS DNA. It hybridized almost exclusively with DNA banding at $1.694 \mathrm{~g} / \mathrm{ml}$ (Table 4).

\section{Density Centrifugation of Nonsheared DNA}

To prove that $\mathrm{H}$ and $\mathrm{L}$ portions are parts of a single, formerly unique molecule, ${ }^{3} \mathbf{H}$ thymidine labeled virus concentrates were lysed directly on top of cesium chloride solutions with $2 \%$ sarkosyl prior to equilibrium centrifugation. Under these condi-

\section{TABLE 3}

Hybridization of HVS-Specific cRNA with DNA FROM VIRUS-INFECTLD AND UNINFECTED CELLS ${ }^{a}$

\begin{tabular}{|c|c|c|c|}
\hline \multicolumn{2}{|c|}{ DNA from } & \multirow{2}{*}{$\begin{array}{c}\text { H-cRNA } \\
15,900 \mathrm{dpm} \\
\text { input } \\
(\%)\end{array}$} & \multirow{2}{*}{$\begin{array}{c}\text { L-cRNA } \\
23,500 \\
\text { dpm input } \\
(\%)\end{array}$} \\
\hline $\begin{array}{l}\text { Virus } \\
\text { strain }\end{array}$ & OMK cell line & & \\
\hline S $295 \mathrm{C}$ & OMK-VZ & 29.4 & 30.4 \\
\hline E $940 \mathrm{~F}$ & & 23.3 & 39.7 \\
\hline E 515 I & & 36.3 & 50.8 \\
\hline 11 & & 26.8 & 37.0 \\
\hline S $295 \mathrm{C}$ & OMK S $595 \mathrm{~K}$ & 23.8 & 43.1 \\
\hline E $940 \mathrm{~F}$ & & 24.0 & 50.2 \\
\hline E $515 \mathrm{I}$ & & 18.6 & 47.2 \\
\hline 11 & & 24.1 & 40.3 \\
\hline - & $\mathrm{OMK}-\mathrm{VZ}$ & 1.0 & 1.7 \\
\hline - & OMK-S 595K & 0.4 & 1.6 \\
\hline
\end{tabular}

${ }^{a}$ Four HVS-strains were propagated each on two OMK cell lines. Fifty micrograms of cold DNA, extracted from the tissue cultures, was hybridized with cRNA transeribed from the light (L) and heavy (H) fragments of HVS DNA. Hybridization efficiency $(\%)=d p m$ bound to filters/ $\mathrm{dpm}$ added for reaction mixture $\times 100$.

tions, most radioactivity banded at a density of $1.709 \mathrm{~g} / \mathrm{ml}$, obviously corresponding to the mean density of the intact HVS-DNA molecule (Fig. 4A). Nevertheless, in these experiments also, the formation of $\mathrm{H}$ and $\mathrm{L}$ fragments could not be avoided. H-DNA appeared as distinct peak at $1.729 \mathrm{~g} / \mathrm{ml}$, 

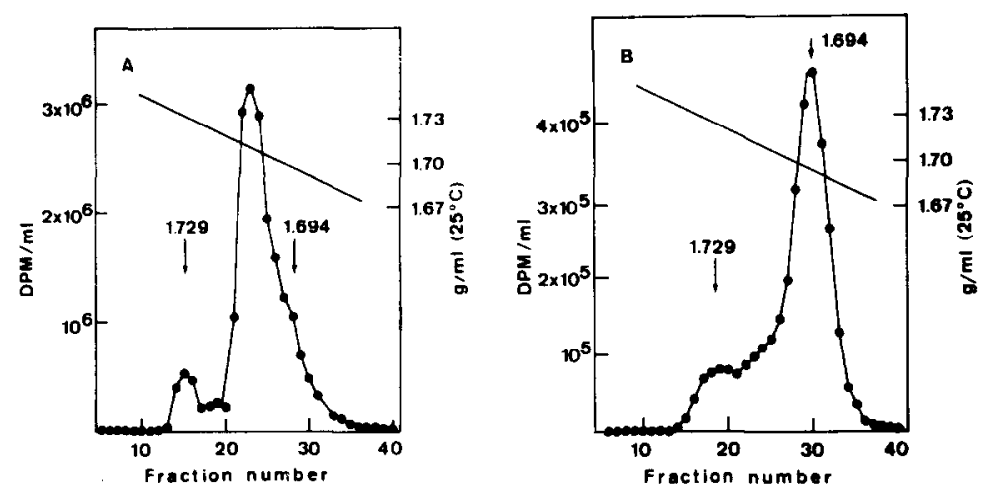

FIG. 4. (A) Density gradient centrifugation of nonsheared HVS-DNA. Partially purified virus was lysed with $2 \%$ sarkosyl on top of a $1.7 \mathrm{~g} / \mathrm{ml}$ cesium chloride solution prior to centrifugation. A maximum of nonsheared DNA appeared at $1.709 \mathrm{~g} / \mathrm{ml}$. $\mathrm{H}$ fragments formed a peak at $1.729 \mathrm{~g} / \mathrm{ml}$; L fragments, a shoulder at $1.694 \mathrm{~g} / \mathrm{ml}$. The DNA in fractions 21 and 22 was sheared and recentrifuged. (B) The fragments banded over a broad density range with two maxima at the sites characteristic for $\mathrm{L}_{-}$and H-DNA.

TABLE 4

HYBRIDIZATION OF L-STRAND CRNA WITH THE HVS-DNA of Different Densities ${ }^{a}$

\begin{tabular}{ccc}
\hline $\begin{array}{c}\mathrm{H} \text { strand, } \\
1.729 \mathrm{~g} / \mathrm{ml}\end{array}$ & Intermediate & $\begin{array}{c}\mathrm{L} \text { strand, } \\
1.694 \mathrm{~g} / \mathrm{ml}\end{array}$ \\
\hline $0.5 \%$ & $2.5 \%$ & $16.1 \%$ \\
\hline
\end{tabular}

a DNA of nonlabeled HVS-virions, purified by neutral sucrose gradient sedimentation and fractionated by cesium chloride density centrifugation, was hybridized with cRNA transeribed from the $\mathrm{L}$ fragment of HVS-DNA. There is no indication for significant cross-hybridization between $\mathrm{H}$ and L strands. Input, 20,000 dpm; hybridization efficiency $(\%)=\mathrm{dpm}$ bound to filters/dpm added to reaction mixture $\times 100$.

and the $\mathrm{L}$ strands formed a shoulder in the radioactivity profile as indicated in Fig. $4 \mathrm{~A}$.

Intact DNA which banded at $1.709 \mathrm{~g} / \mathrm{ml}$ was sheared by repetitive squirting through a pipette tip. The breakdown products were again subjected to equilibrium centrifugation in cesium chloride. They banded over a broad density range with two maxima at the sites typical for $\mathrm{L}$ and $\mathrm{H}$ fragments (Fig. 4B).

\section{DISCUSSION}

In our hands, approximately 5 liters of OMK tissue cultures were needed to purify $1 \mu \mathrm{g} \mathrm{H}$-HVS DNA. Owing to this low yield, only two methods seemed to be suited to calculate the molccular weight of HVS DNA.
1. Becker et al. (1968) determined the molccular wcight of horpes simplex type 1 DNA by using the Kleinschmidt technique of direct length measurement in the electron microscope. There are several problems connected with this method, since some factors, e.g., ionic strength, single-strand breakages, and $\mathrm{C}+\mathrm{G}$ content, affect the DNA mass per unit length (Freifelder, 1970).

2. The accuracy of DNA molecular weight determination by zone sedimentation in the preparative ultracentrifuge hinges on the absolute measurement of the size of a useful internal marker molecule. T4 phage DNA molecular weight has been absolutely measured in the analytical ultracentrifuge by sedimentation equilibrium centrifugation in a density gradient and found to be $\mathbf{1 1 3 . 5}$ $\times 10^{6}$ daltons (Schmid and Hearst, 1969; Freifelder, 1970). Dublin et al. (1970) calculated $105.7 \times 10^{6}$ daltons from phosphorus and nitrogen content of T4 phage (Bancroft and Freifelder, 1970). Its total molecular weight was determined by optical mixing spectroscopy. Therefore, T4 DNA, approximating the molecular weight of DNA of herpesviruses, served as an internal marker for zone sedimentation of herpes simplex virus DNA in a neutral sucrose gradient (Kieff et al., 1971).

We also used the zone sedimentation with T4 marker DNA and found for HVS DNA an $s_{20, w}^{0}$ of $58 \pm 1.5 \mathrm{~S}$. Using Freifelder's equation $S_{1} / S_{2}=M_{1} / M_{2}{ }^{0.38}$, the appropriate 
molecular weight of $\mathrm{HVS}$ DNA is calculated to be $91 \pm 5 \times 10^{6}$ daltons, if we supposed $110 \times 10^{6}$ daltons for T4 DNA.

In our system herpes simplex virus type 2 DNA showed the same sedimentation behavior as described by Kieff et al. (1971), corresponding to $99 \pm 5 \times 10^{6}$ daltons (Kieff et al., 1971; Frenkel and Roizman, 1971).

Purified HVS DNA appeared as a mixture of DNA portions banding at two different buoyant densities in cesium chloride gradients. The lighter (L) peak banded at $1.694 \mathrm{~g} / \mathrm{ml}$, the heavier $(\mathrm{H})$ at $1.729 \pm$ $0.002 \mathrm{~g} / \mathrm{ml}$ by using three DNA markers of known densities. The latter value corresponds to the one reported by Goodheart (1970), who investigated the DNA of HVSinfected cells in the analytical ultracentrifuge. This author did not describe the lighter (L) DNA, since it was most probably hidden in an excess of cellular DNA.

L-DNA is not cellular, since it does not hybridize with DNA from uninfected cells. Upon labeling with ${ }^{3} \mathrm{H}$-thymidine, its specific activity is characteristic for viral DNA, being 20 -fold higher than for cellular DNA. It is more difficult, however, to prove that L-DNA does not represent DNA of mycoplasms (PPLO) or that it is not contaminated with PPLO-DNA. There exist a large number of mycoplasma species possibly contaminating tissue cultures and virus stocks, and no evidence has been presented for cross hybridization of their DNAs. Therefore hybridizations with a particular PPLO-DNA can not solve this problem. A contamination of the HVS-DNA used in these tests with mycoplasma DNA is unlikely, however, for the following reasons:

1. Cell lines and virus stocks were controlled independently in different laboratories by mycoplasma isolation procedures and found to be negative. Since these methods are not reliable enough, the cultures were routinely examined by orcein staining (Fogh and Fogh, 1964) and by a slight modification of the uridine phosphorylase assay which was described by Levine (1972) and considered by the author to be the most sensitive PPLO-detection method. All tests gave negative results.

2. The two typical pcaks of HVS-DN $\Lambda$ were independent of virus strain and cell line used prior to DNA purification.

3. cRNA transcribed separately from $\mathbf{H}$ and L-DNA showed no significant hybridization with DNA from uninfected cells. It reassociated, however, to a high extent with DNA from tissue cultures which were infected with HVS strains of various origins.

4. Electron micrographs of viral material banding after sedimentation velocity centrifugation showed no indication of PPLO contamination.

5. Mock infected OMK-cells as well as HVS-infected, but nonpermissive, BHK cells were labeled with ${ }^{3} \mathrm{H}$-thymidine. In addition, HVS-infected OMK-cells were treated with ${ }^{3} \mathrm{H}$-uridine. The cultures were processed analogously to the virus purification methods. In none of these experiments were viruslike radioactivity peaks obtained.

6. Mycoplasma laidlawii, a possible contaminant, was cultured in suspension, concentrated, and tested for its sedimentation behavior; it was found to be separable from herpesviruses.

7. The radioactive profile of HVS-DNA in cesium chloride gradients was uniform and the ratio of L-DNA to H-DNA was independent of the preceding virus purification method.

8. Owing to its higher adenine plus thymine content, the specific activity of ${ }^{3} \mathrm{H}$ thymidine labeled L-DNA is 2.2 times higher than that of $\mathrm{H}-\mathrm{DNA}$; this ratio must be expected if both DNAs are synthesized from one intracellular nucleotide pool.

Shearing of HVS-DNA which previously banded at $1.709 \mathrm{~g} / \mathrm{ml}$ yielded fragments banding as $\mathrm{L}$ and $\mathrm{H}$ portions at different densities. Therefore, we assume that the HVS genome breaks by most manipulations in two double-stranded DNA fragments. One, $42 \%$ of the parental molecule, has a base composition of $70 \% \mathrm{C}+\mathrm{G}$, and the other one, $58 \%$ of the parental molecule, has $35 \% \mathrm{C}+\mathrm{G}$ content. A similar phenomenon has becn observed by density centrifugations of murine cytomegalovirus DNA (Plummer et al., 1969; Mosmann and Hudson, 1973).

DNA-DNA-annealing studies did not reveal significant cross hybridization between the two DNA species. Even if there exists a 
small piece of ${ }^{3} \mathrm{H}-\mathrm{L}-\mathrm{DNA}$ hybridizing with H-DNA, which escapes detection by this method, it must represent less than $2 \%$ of the $\mathrm{L}$ fragment. Therefore, the fragmentation of the HVS genome to the $\mathrm{H}$ and $\mathrm{L}$ fragment takes place within a small circumscribed region of the molecule.

If the $\mathrm{H}$ and $\mathrm{L}$ fragments share any sequences close to the breakage region, they are not transcribed in vitro by $E$. coli polymerase.

Preferential breakage points were reported by Hershey and Burgi (1962) for nicked DNA of phage T5. Kieff et al. (1971) and Frenkel and Roizman (1972) described specific nicks in the DNA of herpes simplex virus. Our results suggest that the HVS genome has a single preferential breakage point between the $\mathrm{H}$ and the $\mathrm{L}$ portion.

The specific fragmentation of Herpesvirus saimiri DNA and the achieved separation of the fragments provide useful tools in studying HVS-host cell interactions at the genetic level and in examining the role of the specific fragments in malignant transformation.

\section{ACKNOWLEDGMENTS}

We thank Dr. Harald zur Hausen and Dr. Reiner 'Thomssen for helpful suggestions and discussions. The excellent technical assistance of Miss C. Boltz is greatly appreciated.

\section{REFERENCES}

Ablashi, D. V., Loeb, W. F., Valerio, M. G., Adamson, R. H., Armstrong, G. R., Bennet, D. G., and Heine, U. (1971). Malignant lymphoma with lymphocytic leukemia induced in owl monkeys by Herpesvirus saimiri. J. Nat. Cancer Inst. 47, 837-855.

Bancroft, F. C., and Freifelder, D. (1970). Molecular weights of coliphages and coliphage DNA. I. Measurement of the molecular weight of bacteriophage T7 by high-speed equilibrium centrifugation. J. Mol. Biol. 54, 537-546.

Beck Er, Y., Dym, H., and Sarov, I. (1968). Herpes simplex virus DNA. Virology 36, 184-192.

Burgi, E., and Hershey, A. D. (1963) Sedimentation rate as a measure of molecular weight of DNA. Biophys. J. 3, 309-321.

Deinhardt, F., Falk, L. A., and Wolfe, L. G. (1973). Simian herpesviruses and neoplasia, in press.

Dubin, S. B., Benedek, G. B., Bancroft, F. C., and Freifrider, D. (1970). Molecular weights of coliphages and coliphage DNA. II. Measurement of diffusion coefficients using optical mixing spectroscopy, and measurement of sedimentation coefficients. J. Mol. Biol. 54, 547-557.

Epstein, M. A., Achong, B. G., and Barr, Y. M. (1964). Virus particles in cultured lymphoblasts from Burkitt's lymphoma. Lancet 1, 702-703.

Epstein, M. A., Hunt, R. D., and Rabin, H. (1973). Pilot experiments with EB virus in owl monkeys (A otus trivirgalus). I Reticuloproliferative disease in an inoculated animal. Int. $J$. Cancer 12, 309-318.

Falk, L. A., Wolfe;, L. G., and Dernhardt, F. (1972a). Isolation of Herpesvirus saimiri from blood of squirrel monkeys (Saimiri sciureus). Nat. Cancer Inst. 48, 1499-1505.

Falk, L. A., Wolfe, L. G., Hoekstra, J., and DeinhardT, F. (1972b). Demonstration of Herpesvirus saimiri-associated anigens in peripheral lymphocytes from infected marmosets during in vitro cultivation. $J$. Nat. Cancer Inst. 48, 523-530.

Fogh, J., and Fogh, H. (1964). A method for direct demonstration of pleuropneumonia-like organisms in cultured cells. Proc. Soc. Exp. Biol. Med. 117, 899-901.

Freifelder, D. (1970). Molecular weights of coliphages and coliphage DNA. IV. Molecular weights of DNA from bacteriophages $\mathrm{T} 4, \mathrm{~T} 5, \mathrm{~T} 7$ and general problem of determination of M. $J$. Mol. Biol. 54, 567-577.

Frenkel, N., and Roizman, B. (1971). Herpes simplex virus: Genome size and redundancy studied by renaturation kinetics. J. Virol. 8, 591-593.

Frenkel, N., and Rorzman, B. (1972). Separation of the herpesvirus deoxyribonucleic acid duplex into unique fragments and intact strand on sedimentation in alkaline gradients. J. Virol. 10, $565-572$.

GoodHEaRT, C. R. (1970). Herpesviruses and cancer. J. Amer. Med. Ass. 211, 91-96.

Gray, H. B., and Hearst, J. E. (1968). Flexibility of native DNA from the sedimentation behavior as a function of molecular weight and temperature. J. Mol. Biol. 35, 111-129.

Henle, G., Henle, W., Chrfford, P., Diehl, V., Kafuko, G. W., Kirya, B. G., Klein, G., Morrow, R. H., Munube, G. M. R., Pike, P., Tukei, P., and Ziegler, J. (1969). Antibodies to Epstein-Barr virus in Burkitt's lymphoma and control groups. J. Nat. Cancer Inst. 43, 11471157.

Hershey, A. D., and Burgi, E. (1962). Breakage points in T5 DNA. Yearb. Carnegie Inst. Wash. 62, 485 .

KiefF, E. D., Bachenheimer, S. L., and RoizMAN, B. (1971). Size, composition, and structure 
of the deoxyribonucleic acid of herpes simplex virus subtypes 1 and 2. J. Virol. 8, 125-132.

Klein, G., Geering, G., Old, L. J., Henle, G., Henle, W., and Charued, P. (1970). Comparison of the anti-EBV-titer and the EBV-associated membrane reactive and precipitating antibody levels in the sera of Burkitt lymphoma and nasopharyngeal carcinoma patients and controls. Int. J. Cancer 5, 185-194.

Klein, G., Pearson, G., Rabson, A., Artashi, D. V., Falk, L., Wolfe, L., Deinhardt, F., and RABIN, H. (1973). Antibody reactions to Herpes virus saimiri (HVS)-induced early and late antigens (EA and LA) in HVS-infected squirrel, marmoset and owl monkeys. Int. J. Cancer 12, 270-289.

Laufs, R., and Fleckenstein, B. (1972). Malignant lymphoma induced by partially purified Herpesvirus saimiri and recovery of infectious virus from tumorous lymph nodes. Med. Microbiol. Immunol. 158, 135-146.

Laufs, R., and Fleckenstern, B. (1973). Susceptibility to Ilerpesvirus saimiri and antibody development in old and new world monkeys. Med. Microbiol. Immunol. 158, 227-236.

Leona, J., Garapin, A. C., JACKson, N., FANshier, L., Levinson, W., and Bishop, J. M. (1972). Virus-specific ribonucleic acid in cells producing Rous Sarcoma Virus: Detection and characterization. $J$. Virol. 9, 891-902.

LEvine, E. M. (1972). Mycoplasma contamination of animal cell cultures: A simple, rapid detection method. Exp. Cell Res. 74, 99-109.

Melendez, L. V., Daniel, M. D., Hunt, R. D., and Garcta, F. G. (1968). An apparently new herpesvirus from primary kidney cultures of the squirrel monkey (Saimiri sciureus). Lab. Anim. Care 18, 374-381.

Melendez, L. V., Hunt, R. D., Daniel, M. D., Garcia, F. G., and Fraser, C. E. O. (1969). Herpesvirus saimiri. II. Experimentally induced malignant lymphoma in primates. Lab. Anim. Care 19, 378-386.

Mosmann, T. R., and Hudson, J. B. (1973). Some properties of the genome of murine cytomegalovirus (MCV). Virology 54, 135-149.

Plummer, G., Goodheart, C. R., Henson, D., and Bowling, C. P. (1969). A comparative study of the DNA density and behavior in tissue cultures of fourteen different herpesviruses. Virology 39, 134-137.
Rabson, A. S., O'Conor, (4. T., Lorenz, 1). li., Kirschstein, R. L., Lligallais, F. Y., and Tralka, T. S. (1971). Lymphoid cell-culture line derived from lymph node of marmoset infected with Herpesvirus saimiri. Preliminary Report. J. Nat. Cancer Inst. 46, 1099-1109.

Schildkraut, C. L., Marmur, J., and Doty, P. (1962). Determination of the base composition of desoxyribonucleic acid from its buoyant density in CsCl. J. Mol. Biol. 4, 430-443.

Schmid, C. W., and Hearst, J. E. (1969). Molecular weights of heterogeneous coliphage DNA's from density-gradient sedimentation equilib. rium. J. Mol. Biol. 44, 143-160.

Shope, T., Dechairo, D., and Miller, G. (1973). Proc. Nat. Acad. Sci. U.S. 70, 2487-2491.

SutTon, W. D. (1971). A crude nuclease preparation suitable for use in INA reassociation experiments. Biochim. Biophys. A cta 240, 522-531.

WARNER, J. R., KNopF, P. M., and Rich, A. (1963). A multiple ribosomal structure in protein synthesis. Proc. Nat. Acad. Sci. U.S. 49, 122-129.

Weinberg, A., and Becker, Y. (1969). Studies on EB virus of Burkitt's lymphoblasts. Virology $39,312-321$.

Wolf, H., zur Hausen, H., and Becker, V. (1973). EB viral genomes in epithelial nasopharyngeal carcinoma cells. Nature (London) 244, 245-247.

Wolfe, L. G., Falk, A. L., and Deinhardt, F. (1971). Oncogenicity of Herpesvirus saimiri in marmoset monkeys. J. Nat. Cancer Inst. 47, 1145-1162.

zur Hausen, H., and Schulte-Holthausen, H. (1970). Presence of EB virus nucleic acid homology in a "virus free" line of Burkitt tumor cells. Nalure (London) 227, 245-248.

zur Hausen, $H$. and Schulte-Holthausen, $H$. (1972). Detection of Epstein-Barr viral genomes in human tumour cells by nucleic acid hybridization. "Symposium on Oncogenesis and Herpesviruses" (P. M. Biggs, G. de Thé, and L. N. Payne, eds.). IARC Lyon 321.

zur Hausen, H., Schulte-Holthausen, H., Klein, G., Henlf, W., Henle, G., Clifford, P., and SAnTesson, L. (1970). EBV-DNA in biopsies of Burkitt tumour and anaplastic carcinomas of the nasopharynx. Nature (London), 228, 1056-1058. 